\title{
Pengaruh Pemberian Konseling Gizi terhadap Penurunan Kadar Kolesterol Darah
}

\author{
Agus Hendra Al Rahmad \\ Jurusan Gizi, Politeknik Kesehatan Kemenkes Aceh, Indonesia \\ Email: 4605.ah@gmail.com
}

\begin{abstract}
Impact of Nutritional Counseling in Reducing Blood Cholesterol. Technological and socioeconomic advances resulted in dietary changes from the traditional diet to the western diet such as high-calorie fast food and fat, thus impacting the high prevalence of cholesterol in the community. One effort to reduce blood cholesterol can be done through consultation or counseling with a nutritionist. The study aimed to measure the effect of nutritional counseling on the decrease of cholesterol. This quasi-experimental study has used a sample of 48 patients of health center in the Banda Aceh City, divided into case and control groups through non-random assignment. Cholesterol data obtained through laboratory blood tests, and the tool used for its testing is Autocheck with scale ratio, while the variable method of counseling is done face to face with a tool leaflet. Analysis using a t-test. The results showed a decrease in blood cholesterol in patients given nutritional counseling using a leaflet medium of $20,2 \mathrm{mg} / \mathrm{dl}(\mathrm{p}=0,000)$, while in the control group (counseling without media) also showed a decrease in cholesterol levels of $6,9 \mathrm{mg} / \mathrm{dl}(\mathrm{p}=0.001)$. Counseling methods using leaflets have a better value of effectiveness than without the media. Conclusion, the provision of nutrition counseling is very influential on the decline in blood cholesterol, and the use of media leaflets better in nutrition counseling. Suggestion, every health services should cooperate with universities to conduct nutritional counseling routinely and become one of program priority in the handling of degenerative diseases.
\end{abstract}

Keywords: Blood cholesterol, Counseling, Media leaflet

\begin{abstract}
Abstrak: Pengaruh Pemberian Konseling Gizi terhadap Penurunan Kadar Kolesterol Darah. Kemajuan teknologi dan sosial ekonomi mengakibatkan perubahan pola makan dari pola makan tradisional ke pola makan barat seperti fast food yang tinggi kalori serta lemak sehingga berdampak tehadap tingginya prevalensi kolesterol pada masyarakat. Salah satu upaya untuk menurunkan kolesterol darah dapat dilakukan melalui konsultasi atau konseling dengan ahli gizi. Penelitian bertujuan untuk mengukur pengaruh pemberian konseling gizi terhadap penurunan kadar kolesterol. Penelitian quasi-eksperimen ini menggunakan sampel 48 pasien puskesmas Kota Banda Aceh yang terbagi ke dalam kelompok kasus dan kontrol melalui non-random assignment. Data kolesterol diperoleh melalui pemeriksaan darah secara laboratorium dengan skala rasio, pemeriksaan kolesterol menggunakan Autocheck, sedangkan variabel metode konseling dilakukan secara tatap muka dengan alat bantu leaflet. Analisis menggunakan uji t. Hasil penelitian menunjukan terjadi penurunan kadar kolesterol pada pasien yang diberikan konseling gizi menggunakan media leaflet sebesar 20,2 mg/dl ( $p=0,000)$, sedangkan pada kelompok kontrol (konseling tanpa media) juga menunjukan penurunan kadar kolesterol sebesar 6,9 mg/dl ( $p=0,001)$. Metode konseling menggunakan leaflet mempunyai nilai efektifitas yang lebih baik dibandingkan tanpa media dalam mendukung konseling untuk menurunkan kadar kolesterol. Kesimpulan, pemberian konseling gizi sangat berpengaruh terhadap penurunan kadar kolesterol, dan penggunaan media leaflet lebih baik dalam melakukan konseling gizi. Saran, setiap puskesmas sebaiknya bekerja sama dengan pihak perguruan tinggi untuk menyelenggarakan konseling gizi secara rutin dan menjadi salah satu prioritas program dalam penanggulangan penyakit degeneratif.
\end{abstract}

Kata kunci: Kadar kolesterol, Konseling gizi, Media leaflet

Pesatnya perkembangan teknologi dan informasi pada era globalisasi maka industri-industri makanan juga berkembang begitu sangat pesat. Selain memberikan dampak positif ternyata juga dapat berdampak negatif bagi manusia sendiri. Hal tersebut tanpa disadari menjadi bagian dari hidup manusia. Salah satu dampak negatif dari perkembangan teknologi dan informasi adalah terjadinya pergeseran pola hidup masyarakat menjadi lebih buruk (WHO, 2016). 
Pola hidup yang buruk seperti konsumsi makanan tidak sehat seperti makanan siap saji (junk food), kurangnya aktifitas fisik dan olahraga bagi ibu-ibu dan lansia berdampak terhadap kondisi kesehatan. Salah satu dampak tersebut adalah tingginya kadar kolesterol (hiperkolesterolemia) dalam tubuh, yang dapat menjadi pemicu timbulnya berbagai gangguan kesehatan, seperti obesitas, hipertensi, gangguan jantung (penyakit jantung koroner), resistensi insulin, diabetes mellitus tipe 2 hingga stroke (Ogden et al., 2010).

Kolesterol adalah lemak berwarna kekuningan dan berupa seperti lilin yang diproduksi oleh tubuh manusia terutama di dalam hati (Nilawati et al., 2008). Kolesterol merupakan lemak yang penting namun jika terlalu berlebihan dalam darah dapat membahayakan kesehatan, bila ditinjau dari sudut kimiawi kolesterol diklasifikasikan ke dalam golongan lipid (lemak) berkomponen alkohol steroid (Al-Rahmad et al., 2016). Kolesterol umumnya terjadi pada perempuan, dengan kecenderungan mempunyai kadar kolesterol yang tinggi, sehingga pada perempuan lebih beresiko mengalami peningkatan kolesterol (Ujani, 2016).

Kolesterol merupakan manifestasi dari masalah gizi lebih, yang perlu mendapatkan perhatikan karena prevalensi kolesterol dari tahun ke tahun terus meningkat. Kadar kolesterol tinggi merupakan salah satu problema yang sangat serius karena merupakan salah satu faktor paling utama untuk terjadinya penyakit jantung seseorang, masalah lainnya ialah pada seseorang bertekanan darah tinggi dan perokok (Listyaningsih et al., 2018).

Data WHO menunjukan bahwa penyakit kardiovaskuler membunuh lebih banyak orang setiap tahunnya, menurut WHO penyakit kardiovaskuler adalah penyebab nomor satu kematian di seluruh dunia. Lebih banyak orang meninggal setiap tahunnya disebabkan oleh gangguan kardiovaskuler dibandingkan penyebab lainnya. 1,4 juta kematian di negara maju diakibatkan karena penyakit jantung iskemik (WHO, 2016). American Heart Association (AHA) memperkirakan lebih dari 100 juta penduduk Amerika memiliki kadar kolesterol total $>200 \mathrm{mg} / \mathrm{dl}$, yang termasuk kategori cukup tinggi, dan lebih dari 34 juta penduduk dewasa Amerika memiliki kadar kolesterol $>240 \mathrm{mg} / \mathrm{dl}$, yang termasuk tinggi dan membutuhkan terapi (Smith, 2007).

Dampak tingginya prevalensi penyakit kardiovaskuler dinegara berkembang yaitu tingginya angka kematian mencapai sekitar 5,7 juta, dan di Indonesia sendiri menurut hasil dari
Riskesdas 2013, penyakit yang disebabkan karena kardiovaskuler seperti jantung koroner, gagal jantung dan stroke mempunyai prevalensi yang masih tinggi, terutama stroke, yaitu $46,1 \%$ pada usia $<75$ tahun dan $67 \%$ pada usia $\geq 75$ tahun (Balitbangkes, 2013a).

Provinsi Aceh berdasarkan data riset kesehatan dasar terkait prevalensi jantung koroner menurut diagnosis dokter sebesar 2,3\%, gagal jantung mencapai $0,3 \%$ serta prevalensi stroke lebih tinggi yaitu 62,8\%. Prevalensi penyakit jantung koroner, gagal jantung, dan stroke terlihat meningkat seiring peningkatan umur responden. Prevalensi stroke pada laki-laki lebih tinggi daripada perempuan (Balitbangkes, 2013b). Penyebab tinggi kasus penyakit jantung karena gaya hidup masyarakat yang suka mengkonsumsi makanan yang mengandung kolesterol tinggi dan makanan manis mencapai sebesar 90\% dari penduduk Kota Banda Aceh (Sari et al., 2014).

Kadar kolesterol tinggi seringkali tidak menimbulkan dampak, orang sering kali tidak sadar bahwa mereka menyandang hiperkolesterolemia familial atau kelainan lipid dalam darah (Bull and Morrell, 2007). Oleh karena itu, perlu adanya proses untuk dapat menurunkan kadar kolesterol tinggi yang terkandung dalam darah.

Menurunkan kadar kolesterol tidak harus dengan menggunakan obat obatan, tetapi dapat dilakukan dengan berkonsultasi/konseling kepada ahli gizi atau dengan menggunakan metode berolahraga (Herwati and Sartika, 2013). Tujuan pemberian konseling gizi adalah untuk meningkatkan pola pikir dari segi pengetahuan pasien mengenai kolesterol, agar pasien dapat mematuhi/menaati aturan diet kolesterol sehingga dapat menurunkan kolesterol darah (Yuliantini and Maigoda, 2011). Konseling gizi adalah serangkaian kegiatan sebagai proses komunikasi dua arah untuk menanamkan dan meningkatkan pengertian, sikap, serta perilaku sehingga membantu klien atau pasien mengenali dan mengatasi masalah gizi melalui pengaturan makanan dan minuman (Sukraniti and Ambartana, 2011).

Upaya-upaya bersifat edukatif dan preventif perlu dilaksanakan. Penatalaksanaan masalah tinggi kolesterol masyarakat di Indonesia mencakup terapi non-farmakologis yang disebut perubahan gaya hidup terapeutik Therapeutic Lifestyle Changes (TLC) dan penggunaan obat-obat penurun kolesterol. Konseling secara personal juga merupakan salah satu peran pelayanan kesehatan dalam menciptakan perubahan pola hidup dan pola makan (Yuliantini 
and Maigoda, 2011).

Pengumpulan data awal yang dilakukan di beberapa Puskesmas Kota Banda Aceh menunjukan tingginya penderita kolesterol (tinggi trigliserida) yaitu mencapai 391 pasien pada bulan Februari 2018. Banyaknya jumlah pasien menderita kolesterol yang tinggi perlu diberikan konseling gizi dalam upaya memperbaiki kualitas hidup pasien dan meningkatkan derajat kesehatan masyarakat Kota Banda Aceh.

\section{METODE}

Jenis penelitian eksperimen dan menggunakan desain Quasi Experimental melalui pre-test post-test non-equivalent group yaitu suatu pendekatan eksperimen yang mengontrol situasi rancangan sebelum dan sesudah intervensi menggunakan kelompok sebagai pembanding, dengan sarasan bersifat non-random assignment (AL Rahmad and Miko, 2017). Penelitian dilaksanakan di Kota Banda Aceh dengan melibatkan 48 pasien dari beberapa puskesmas terpilih, kelompok sampel dibagi menjadi kelompok kasus (diberikan konseling dengan media leaflet yang merupakan modifikasi leaflet dari penelitian lain) dan kelompok kontrol (konseling tanpa media). Konseling dilakukan selama dua kali dalam semingu. Penelitian dilaksanakan Februari-Maret 2018.

Pengumpulan data dilakukan secara wawancara dan pemeriksaan laboratorium. Data yang dikumpulkan yaitu data karakteristik pasien diperoleh secara wawancara menggunakan kuesioner, sedangkan data kadar kolesterol diperoleh dari hasil pemeriksaan darah laboratorium menggunakan alat Accu-cek, dilakukan sebelum diberikan konseling dan setelah diberikan konseling. Data konseling gizi pada kelompok kasus dilakukan secara tatap muka hanya satu kali setiap masing-masing pasien dengan alat bantu leaflet, sedangkan pada kelompok kontrol konseling dilakukan tanpa penggunaan leaflet. Konseling dilakukan oleh konselor dari Jurusan Gizi Politeknik Kesehatan Kemenkes Aceh di puskesmas terpilih sebanyak 2 orang, dengan syarat telah mengikuti pelatihan dan edukasi pendidikan gizi.

Analisis data pada penelitian ini menggunakan software R-Statistik open source. Pengujian prasyarat analisis penting dilakukan pada pendekatan statistik parametrik mengingat model distribusi dan variansi antar kelompok data yang ada. Pengujian pra-syarat analisis menggunakan uji Kolmogorov Smirnov diperoleh bahwa data kadar kolesterol berdistribusi normal (p-value $>0,05)$, pengujian normalitas dilakukan pada data kadar kolesterol baik sebelum maupun setelah diberikan konseling. Selanjutnya dalam menjawab tujuan penelitian serta membuktikan hipotesis, digunakan analisis uji statistik yaitu Dependent T-test dan independent T-test yaitu untuk mengukur pengaruh konseling terhadap penurunan kadar kolesterol pasien.

\section{HASIL}

\section{Karakteristik Responden}

Berdasarkan hasil penelitian (Tabel 1) didapatkan jumlah sampel sebanyak 48 orang pasien, terdiri dari 24 orang yang diberikan konseling gizi menggunakan media leaflet (kelompok kasus) dan 24 orang diberikan konseling gizi tanpa media (kelompok kontrol) yang mengalami kolesterol tinggi di Kota Banda Aceh. Jumlah sampel yang diambil terdiri dari laki-laki dan perempuan dengan umur antara 25-70 tahun.

\section{Tabel 1. Karakteristik Responden}

\begin{tabular}{lrrrrr}
\hline Karakteristik & \multicolumn{2}{c}{ Perlakuan } & \multicolumn{2}{c}{ Kontrol } & Nilai $\boldsymbol{p}$ \\
\cline { 2 - 4 }$\quad$ Sampel & $\mathbf{n}$ & \multicolumn{1}{c}{$\%$} & \multicolumn{1}{c}{ n } & \% & \\
\hline Jenis Kelamin & & & & & \\
$\quad$ Laki-laki & 3 & 12,5 & 3 & 12,5 & 1,000 \\
$\quad$ Perempuan & 21 & 87,5 & 21 & 87,5 & \\
Umur & & & & & \\
$\quad 26-45$ tahun & 13 & 54,1 & 17 & 70,7 & 0,233 \\
$\quad 46-65$ tahun & 11 & 45,9 & 7 & 29,3 & \\
Pendidikan & & & & & \\
$\quad$ Tinggi & 13 & 54,1 & 13 & 54,1 & 0,176 \\
$\quad$ Menengah & 8 & 33,3 & 11 & 45,8 & \\
$\quad$ Rendah & 3 & 12,5 & 0 & 0,0 & \\
Pendapatan & & & & & \\
$\quad$ Tinggi & 15 & 62,5 & 12 & 50,0 & 0,383 \\
$\quad$ Rendah & 9 & 37,5 & 12 & 50,0 & \\
Pekerjaan & & & & & \\
$\quad$ PNS & 7 & 29,1 & 3 & 12,5 & 0,289 \\
$\quad$ Wiraswasta & 4 & 16,6 & 1 & 4,1 & \\
$\quad$ Honorer & 1 & 4,1 & 1 & 4,1 & \\
Pedagang & 2 & 8,3 & 3 & 12,5 & \\
$\quad$ IRT & 10 & 41,6 & 16 & 66,6 & \\
\hline$\quad$ Jumlah & 24 & 100,0 & 24 & 100,0 & \\
\hline & & & & &
\end{tabular}

Hasil uji statistik menunjukan bahwa kedua kelompok sampel tidak menunjukan perbedaan secara proporsional $(p>0,05)$, terlihat hampir menunjukan proporsi yang sama pada setiap karakteristik seperti proporsi jenis kelamin lebih banyak perempuan dibandingkan wanita, umur pada kedua kelompok umumnya di bawah 46 tahun, pendidikan mayoritas berpendidikan tinggi baik pada perlakuan maupun kontrol dan juga diikuti oleh pendapatan. Berdasarkan pekerjaan, 
antara kelompok perlakuan dengan kontrol masing-masing hampir mempunyai proporsi yang sama, yaitu bekerja sebagai IRT. Sehingga dapat dipastikan bahwa variabel karakteristik bukan sebagai faktor perancu terhadap pengaruh konseling dengan penurunan kadar kolesterol.

\section{Kadar Kolesterol Darah}

Berdasarkan Tabel 2 dapat dilihat bahwa pada kedua kelompok intervensi mempunyai kadar kolesterol yang tinggi diatas $200 \mathrm{mg} / \mathrm{dl}$ baik pada kelompok perlakuan maupun pada kelompok kontrol. Pada kelompok perlakuan yang diberikan konseling menggunakan media leaflet, sebelum diintervensi mempunyai rata-rata kadar kolesterol $233,7 \mathrm{mg} / \mathrm{dl}$ dan setelah diintervensi kadar kolesterol pasien menurun menjadi 213,5 mg/dl. Begitu juga dengan kelompok kontrol, pada kelompok ini pasien hanya diberikan konseling tanpa media leaflet. Hasil menunjukan juga terjadi penurunan kadar dari 224,5 mg/dl menjadi 217,6 $\mathrm{mg} / \mathrm{dl}$.

Masing-masing pasien di puskesmas yang pernah mendapakan konseling gizi dapat diturunkan nilai atau kadar kolesterol dalam darah. Namun demikian, pasien yang diberikan konseling gizi menggunakan media leaflet mempunyai nilai rerata yang sama dengan pasien yang mendapatkan konseling gizi tanpa media.

\section{Pengaruh Konseling Gizi terhadap Penurunan Kadar Kolesterol}

Proporsi pada setiap karakteristik seperti proporsi jenis kelamin, pendidikan, pendapatan serta pekerjaan menunjukan kesamaan atau berasal dari kelompok yang sama dan tidak menunjukan perbedaan proporsi antara kelompok perlakuan dengan kelompok kontrol, sebagaimana telah disajikan pada tabel 1 Sehingga dapat dipastikan bahwa variabel karakteristik bukan sebagai faktor perancu terhadap pengaruh konseling dengan penurunan kadar kolesterol.

Hasil statistik sebagaimana tabel 2, diketahui bahwa terjadi penurunan kadar kolesterol darah setelah diberikan konseling gizi baik pada kelompok yang menggunakan media leaflet maupun pada kelompok tanpa media. Penurunan kadar kolesterol pada kelompok yang menggunakan media leaflet yaitu sebesar 20,2 $\mathrm{mg} / \mathrm{dl}$ dengan deviasi 15,80 mg/dl. Secara statistik terbukti bahwa terdapat perbedaan signifikan ( $p$-value $<0,01)$ antara kadar kolesterol sebelum dengan setelah konseling menggunakan leaflet pada pasien, dengan nilai $p=0,000$. Hasil statistik ini dapat disimpulkan bahwa konseling gizi menggunakan media leaflet dapat menurunkan kadar kolesterol darah pasien di puskesmas wilayah Kota Banda Aceh.

Selanjutnya juga terjadi penurunan kadar kolesterol darah pada kelompok yang hanya mendapatkan konseling gizi tanpa menggunakan media, penurunan kadar tersebut relatif lebih kecil yaitu sebesar $6,9 \mathrm{mg} / \mathrm{dl}$ dengan deviasi $6,26 \mathrm{mg} / \mathrm{dl}$. Hasil statistik juga membuktikan terdapat perbedaan signifikan $(p$-value $<0,01)$ antara kadar kolesterol sebelum dengan setelah konseling gizi tanpa menggunakan media pada pasien, dengan nilai $p=0,001$. Hal ini menunjukan bahwa, konseling gizi dapat menurunkan kadar kolesterol darah pasien di puskesmas wilayah Kota Banda Aceh walaupun tanpa penggunaan media.

Tabel 2. Kadar Kolesterol Darah Sebelum dan Sesudah Pemberian Konseling Gizi pada Pasien

\begin{tabular}{lrrrrr}
\hline $\begin{array}{c}\text { Kadar Kolesterol Kelompok } \\
\text { Intervensi }\end{array}$ & \multirow{2}{*}{ Min - Max } & Rerata \pm SD & $\begin{array}{c}\text { Selisih Rerata } \pm \\
\text { SD }\end{array}$ & CI: 95\% & p-value \\
\hline $\begin{array}{l}\text { Konseling Gizi dengan } \\
\text { Media Leaflet }\end{array}$ & & & & & \\
$\quad$ Sebelum Konseling & $210,0-280,0$ & $233,7 \pm 21,84$ & $20,2 \pm 15,80$ & 13,54 s/d 26,88 & 0,000 \\
$\quad$ Setelah Konseling & $201,0-232,0$ & $213,5 \pm 9,30$ & & & \\
Konseling Gizi tanpa Media & & & & & \\
$\quad$ Sebelum Konseling & $204,0-300,0$ & $224,5 \pm 27,65$ & $6,9 \pm 6,26$ & 4,72 s/d 9,56 & 0,001 \\
$\quad$ Setelah Konseling & $200,0-290,0$ & $217,6 \pm 24,47$ & & & \\
\hline
\end{tabular}

\section{PEMBAHASAN}

Hasil penelitian menunjukan terdapat pengaruh signifikan pemberian konseling gizi baik menggunakan media maupun tanpa media terhadap penurunan kadar kolesterol darah pasien di Puskesmas wilayah Kota Banda Aceh. Pemberian konseling gizi sangat berpengaruh walaupun tidak terlalu besar tanpa menggunakan media, tetapi sangat berperan untuk dapat menurunkan kadar kolesterol darah pasien. Menurut Aurora et al. (2012), ternyata konseling gizi memberikan perubahan gaya hidup pada pasien kolesterol, khususnya perubahan asupan nutrisi. Hasil ini juga searah dengan pendapat Yuliantini and Maigoda (2011), bahwa pemberian 
konseling secara personal merupakan salah satu peran pelayanan kesehatan dalam menciptakan perubahan pola hidup dan pola makan. Upaya edukatif tersebut perlu didukung melalui terapi non-farmakologis yang disebut perubahan gaya hidup terapeutik Therapeutic Lifestyle Changes (TLC) dan penggunaan obat-obat penurun kolesterol. Lebih lanjut Batista and Franceschini (2003) berpendapat bahwa melalui konseling, klien diharapkan dapat memiliki pengetahuan dan keterampilan untuk membuat perubahan yang merupakan penyelesaian masalahnya.

Beberapa penelitian lain yang mendukung hasil penelitian ini yaitu terdapat pengaruh konseling terdapat penurunan kadar kolesterol darah yaitu seperti yang dikemukakan oleh Batista and Franceschini (2003) bahwa terjadi penurunan jumlah pasien dengan kolesterol total tinggi, dari $89,6 \%$ menjadi $47,9 \%$, dan pasien dengan LDL tinggi, menurun dari $82,6 \%$ menjadi $45,7 \%$, sedangkan pada pasien dengan gejala obesitas tingkat 1 dan 2 turun dari 31,9\% menjadi 19,8\% setelah mendapat konseling gizi sesuai SOP.

Hasil penelitian Cheng et al. (2004), yang melakukan penelitian pada penderita hiperkolesterolemia dengan rata-rata usia responden 52 tahun dan dalam penelitian ini tidak menggunakan obat untuk upaya penyembuhan melainkan menggunakan konseling gizi. Responden yang mendapat konseling gizi 4 kali dalam 4 bulan dibandingkan dengan pasien yang tidak mendapat konseling gizi. Pasien yang mendapat konseling mengalami penurunan kolesterol LDL yang bermakna yaitu mencapai rata-rata sebesar 6 sampai 7\%, sedangkan pada kelompok kontrol terjadi penurunan kadar kolesterol LDL yang tidak signifikan dengan rerata sebesar dibawah $1 \%$.

Terdapatnya pengaruh konseling gizi terhadap penurunan kadar kolesterol dalam penelitian ini dimungkinkan oleh tiga faktor yaitu: faktor pendidikan pasien, faktor konselor, dan faktor frekuensi konseling yang diberikan kepada pasien. Penelitian ini memberikan makna bahwa konseling yang dilakukan selama dua kali pertemuan mampu menimbulkan minat dan kesadaran responden. Menurut Aurora et al. (2012), ternyata minat atau kemauan responden maupun keluarga pasien dalam proses pemberdayaan dan kemandirian sangat diperlukan untuk kesuksesan penderita kolesterol agar asupan yang dikonsumsi sesuai dengan anjuran yang telah dipaparkan. Namun demikian, untuk mencapai hasil yang maksimal diperlukan pengetahuan konselor mengenai kolesterol dan tatalaksananya, keterampilan konselor dalam melakukan konseling, serta waktu pertemuan yang memadai untuk menciptakan konseling yang efektif (AL Rahmad and Miko, 2017). Konseling yang efektif seyogianya membutuhkan waktu antara 20 sampai dengan 30 menit untuk setiap pertemuan (Sukraniti and Ambartana, 2011).

Konseling yang diberikan secara bertahap dengan cara ceramah, diskusi, atau sharing sesama penderita kolesterol tinggi yang lebih banyak melibatkan responden, dan diulang-ulang serta review sebelum berlanjut ke pembahasan berikutnya sehingga responden lebih cepat dan mudah menangkap atau memahami pengetahuan yang diberikan (Yani, 2015). Adanya pemberian leaflet yang menjadi pegangan dapat berpengaruh terhadap berhasilnya penyampaian konseling, sehingga konseling gizi tidak hanya berlangsung pada saat bertatap muka tetapi dapat dilakukan mandiri oleh responden (Al Rahmad and Almunadia, 2017). Selain itu, keberadaan materi/modul dan media sangat mendukung terhadap perubahan pengetahuan dan berhasilnya suatu kegiatan konseling. Pendapat tersebut didukung oleh AL-Rahmad and Sudargo (2016), bahwa keberhasilan suatu kegiatan pelatihan atau konseling sangat ditentukan oleh operasional dan proses kegiatan tersebut, seperti pengembangan media, proses pelaksanaan, kebutuhan sarana pendukung seperti pengembangan media dan perlunya evaluasi sehingga peserta semakin cakap dan cepat dalam pengambilan keputusan yang lebih baik, karena technical skill, human skill dan managerial skill-nya telah meningkat. Selain itu penggunaan media sangat efektif dalam meningkatkan pengetahuan melalui edukasi gizi, adapun media yang digunakan yaitu media leaflet atau poster tentang Kadarzi (Hermina and Prihatini, 2015).

Pendidikan juga berkonstribusi terhadap berhasilnya penurunan kadar kolesterol darah pasien. Menurut Wawan dalam AL Rahmad and Miko (2017), faktor pendidikan diperlukan untuk mendapatkan informasi seperti hal yang menunjang kesehatan, sehingga dapat meningkatkan kualitas hidup. Makin tinggi tingkat pendidikan seseorang, makin mudah menerima informasi, sehingga makin banyak pula pengetahuan yang dimiliki, sebaliknya pendidikan yang kurang akan menghambat perkembangan sikap seseorang terhadap nilai-nilai yang baru diperkenalkan. Pendidikan sangat erat kaitannya dengan pengetahuan pasien dalam menerima informasi dari konseling, yang dapat meningkatkan pengetahuan pasien. Seseroang yang berpendidikan lebih tinggi mempunyai pengetahuan yang lebih baik dibandingkan pendidikan rendah (Saragih, 2010). 


\section{SIMPULAN}

Secara statistik, pelaksanaan konseling gizi (menggunakan media leaflet maupun tanpa media) tersebut mempunyai pengaruh positif dalam menurunkan kadar kolesterol dalam darah pada pasien puskesmas di wilayah Kota Banda Aceh. Sehingga merubah pemahaman dan pengetahuan serta pola konsumsi mereka ke arah yang lebih baik.

\section{DAFTAR PUSTAKA}

Al-Rahmad, A. H., Annaria, A. \& Fadjri, T. K. 2016. Faktor Resiko Peningkatan Kolesterol pada Usia Diatas 30 Tahun di Kota Banda Aceh. JURNAL NUTRISIA, vol.18, no.2, 109-114.

AL-Rahmad, A. H. \& Sudargo, T. 2016. Efektivitas Pelatihan Standar Pertumbuhan WHO Anthro terhadap Kualitas dan Informasi Data Status Gizi Balita. Journal of Information Systems for Public Health, vol.1, no.1, 39-46.

Al Rahmad, A. H. \& Almunadia, A. 2017. Pemanfaatan media flipchart dalam meningkatkan pengetahuan ibu tentang konsumsi sayur dan buah. Jurnal Kedokteran Syiah Kuala, vol.17, no.3, 140-146.

AL Rahmad, A. H. \& Miko, A. 2017. Peningkatan Pengetahuan Calon Pengantin Melalui Konseling ASI Eksklusif di Aceh Besar. Buletin Penelitian Kesehatan, vol.45, no.4, 249-256.

Aurora, R. G., Sinambela, A. \& Noviyanti, C. H. 2012. Peran konseling berkelanjutan pada penanganan pasien hiperkolesterolemia. $J$ Indon Med Assoc, vol.62, no.5, 194-201.

Balitbangkes 2013a. Laporan Riset Kesehatan Dasar 2013, Jakarta, Badan Penelitian dan Pengembangan Kesehatan. Kementerian Kesehatan RI.

Balitbangkes 2013b. Laporan Riset Kesehatan Dasar 2013 Provinsi Aceh, Jakarta, Badan Penelitian dan Pengembangan Kesehatan. Kementerian Kesehatan RI.

Batista, M. d. C. R. \& Franceschini, S. d. C. C. 2003. Impact of nutritional counseling in reducing serum cholesterol in public health service patients. Arquivos brasileiros de cardiologia, vol.80, no.2, 167-170.

\section{SARAN}

Perlu tindak lanjut dari tenaga kesehatan di Puskesmas khususnya ahli gizi dalam meningkatkan konseling dan dapat melakukan kerjasama secara baik dengan perguruan tinggi dalam meningkatkan angka kesadaran masyarakat terhadap pola konsumsi yang salah. Kegiatan ini sebagai salah satu rujukan bagi pengambil kebijakan dalam memasyarakatkan konsumsi sayur dan buah untuk meminimalisi tinggtinya prevalensi hiperkolesterolemia di Aceh, yang dapat dilakukan secara intensif dan melibatkan unsur perguruan tinggi.

Bull, E. \& Morrell, J. 2007. Simple Guide: Kolesterol. Jakarta, Erlangga.

Cheng, C., Graziani, C. \& Diamond, J. J. 2004. Cholesterol-lowering effect of the food for heart nutrition education program. Journal of the American Dietetic Association, vol.104, no.12, 1868-1872.

Hermina, H. \& Prihatini, S. 2015. Pengembangan Media Poster dan Strategi Edukasi Gizi untuk Pengguna Posyandu dan Calon Pengantin. Buletin Penelitian Kesehatan, vol.43, no.3, 195-206.

Herwati, H. \& Sartika, W. 2013. Terkontrolnya Tekanan Darah Penderita Hipertensi Berdasarkan Pola Diet dan Kebiasaan Olah Raga di Padang Tahun 2011. Jurnal Kesehatan Masyarakat Andalas, vol.8, no.1, 8-14.

Listyaningsih, K. D., Astuti, H. P. \& Wijayanti, I. B. 2018. Pengaruh konsumsi susu jagung dan senam lansia terhadap tekanan darah dan kadar kolesterol pada lansia. Jurnal Kesmadaska, vol.9, no.1, 115-119.

Nilawati, S., Krisnatuti, D. \& Mahendra, D. 2008. Care Yourself, Kolesterol. Jakarta, Penerbit Plus.

Ogden, C., Carroll, M. D., Curtin, L. R., Lamb, M. M. \& Flegal, K. M. 2010. About childhood obesity. JAMA, vol.303, no.3, 242-249.

Saragih, B. 2010. Kolesterol dan Usaha-Usaha Penurunannya, Yogyakarta, Bimotry

Sari, N., Ahmad, A. \& Arnisam 2014. Asupan serat dan kejadian hiperkolesterolemia pada guru SD di Kecamatan Ulee Kareng Banda Aceh. Nasuwakes, vol.7, no.2, 207-212.

Smith, G. 2007. Epidemiology of dyslipidemia and economic burden on the healthcare system. American journal of managed care, vol.13, no.3, S68. 
Sukraniti, D. P. \& Ambartana, I. W. 2011. Pengaruh Konseling Gizi terhadap Perubahan Kadar Gula Darah Berdasarkan Pengetahuan dan Kepatuhan Diet Penderita Diabetes Melitus di Poliklinik Gizi RSUD Kabupaten Karangasem. J Ilmu Gizi, vol.2, no. $2,100-8$.

Ujani, S. 2016. Hubungan Antara Usia Dan Jenis Kelamin Dengan Kadar Kolesterol Penderita Obesitas RSUD Abdul Moeloek Provinsi Lampung. Jurnal Kesehatan, vol.6, no.1, 43-48.

WHO. 2016. Obesity and Overweight. WHO Int. http://www.who.int/mediacentre/factsheets /fs311/en/ (Accessed 6/1/2017).

Yani, M. 2015. Mengendalikan Kadar Kolesterol pada Hiperkolesterolemia. Jurnal Olahraga Prestasi, vol.11, no.2, 1-7.

Yuliantini, E. \& Maigoda, T. C. 2011. Impact Of Sports And Nutrition Counseling To Blood Pressure And Nutritional Status Based On Waist Circumference In Hypertensive Patients At Bengkulu Municipality. Buletin Penelitian Sistem Kesehatan, vol.14, no.3 Jul, 290-300. 